\title{
PERBANDINGAN NILAI AKTIVITAS ANTIOKSIDAN EKSTRAK DAUN JERUK PURUT (Citrus hystrix) DAN BENTUK LIPOSOMNYA
}

\author{
Kimiko Hikari Zuhria*, Adeltrudis Adelsa Danimayostu ${ }^{\star 凶}$, Siti Jazimah Iswarin*
}

\begin{abstract}
Abstrak
Antioksidan merupakan senyawa yang memiliki mekanisme kontrol dalam menyeimbangkan konsentrasi ROS (Reactive Oxygen Species). Salah satu sumber antioksidan eksogen adalah daun jeruk purut (Citrus hystrix). Daun jeruk purut mengandung sitronelal yang merupakan antioksidan kuat, sehingga dapat dijadikan alternatif antioksidan eksogen untuk penghambat proses penuaan (antiaging). Antioksidan eksogen pada umumnya terpenetrasi dalam kulit hanya hingga bagian epidermis. Padahal, proses penuaanterutama terjadi pada bagian dermis kulit. Sistem penghantaran obat liposom dipilih dengan tujuan meningkatkan kemampuan penetrasi zat aktif kedalam dermis. Penelitian ini bertujuan untuk mengetahui perbandingan antara aktivitas antioksidan ekstrak dan liposom ekstrak daun jeruk purut. Studi eksperimental dilakukan dengan membandingkan ekstrak hasil ekstraksi daun jeruk purut dan bentuk formula liposomnya. Dalam formula liposom, digunakan berbagai konsentrasi lesitin yang berperan sebagai komponen utama penyusun liposom. Variabel yang diukur dalam penelitian ini adalah nilai aktivitas antioksidan dengan metode DPPH. Hasil penelitian menunjukkan bahwa ada perbedaan signifikan antara nilai aktivitas antioksidan yang ditunjukkan oleh nilai $I \mathrm{C}_{50}$ antara ekstrak dengan liposom $(\mathrm{p}<0,05)$. Nilai $I \mathrm{C}_{50}$ ekstrak yaitu $27,434 \mathrm{ppm}$, lebih rendah daripada nilai antioksidan liposom formula A (28,187 ppm), formula B (28,801 ppm) dan formula $C$ (29,876 ppm). Semakin tinggi konsentrasi lesitin menunjukkan hasil $I_{50}$ yang lebih tinggi. Kesimpulan dari penelitian ini adalah ada perbedaan antara aktivitas antioksidan ekstrak dan liposom ekstrak daun jeruk purut.
\end{abstract}

Kata kunci : antioksidan, antipenuaan, daun jeruk purut(Citrus hystrix), liposom

\section{COMPARISON OF ANTIOXIDANT ACTIVITY OF KAFFIR LIME(Citrus hystrix) LEAF EXTRACT AND ITS LIPOSOME FORM}

\begin{abstract}
An antioxidant is a control mechanism substance in balancing the concentration of ROS (Reactive Oxygen Species). One of the sources of exogenous antioxidant is kaffir lime(Citrus hystrix) leaf extract. Kaffir lime contained anantioxidant substance, called citronellal, so it can be an alternative to inhibit aging process.Exogenous antioxidant mostly penetrated only to the epidermal layer of skin, however, aging process mainly happens in the dermal layer. Liposome is chosen as a drug carrier to increase the active compound into the dermis. This research was aimed to compare antioxidant activity of kaffir lime extract and liposome contained the kaffir lime extract by using DPPH method. The liposome were divided into 3 formulas with various concentration of lecithine that is the main component of liposome. The result showed that there was a significant difference between the antioxidant activity of kaffir lime extract and its liposome $(p<0.05)$. The $\mathrm{IC}_{50}$ value of kaffir lime extract was 27.434 ppm, lower than $I_{50}$ value of its liposome formula $A(28.187 \mathrm{ppm})$, formula B (28.801 ppm), and formula $C(29.876 \mathrm{ppm})$. The higher concentration of lecithin makes the higher $\mathrm{IC}_{50}$ value of liposome. In conclusion, there is the different antioxidant activity between kaffir lime extract and kaffir lime liposome.
\end{abstract}

Keywords: antioxidant, antiaging, kaffir lime (Citrus hystrixl), liposome

* Program Studi Farmasi, FK UB

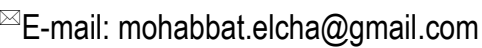




\section{Pendahuluan}

Penuaan kulit merupakan proses dinamis yang dapat terjadi karena proses kronologis maupun photoaging. Akumulasi hasil proses stres oksidatif dan pembentukan radikal bebas di dalam sel kulit merupakan mekanisme umum dari kedua mekanisme proses penuaan. ROS (reactive oxygen species) adalah senyawa pengoksidasi turunan oksigen yang bersifat sangat reaktif. ROS dalam jumlah sedikit berfungsi sebagai second messenger pada jalur sinyal dalam proses proliferasi dan diferensiasi, regulator gen, dan mediator bagi aktivasi sel (faktor kinase dan transkripsi). Konsentrasi ROS dalam jumlah tinggi menyebabkan terjadinya formasi peroksinitrit yang mempengaruhi potensial membran dari mitokondria, yang merupakan kunci dari aktivasi jalur apoptosis sel. ${ }^{1}$

Produksi antioksidan merupakan mekanisme kontrol dari jaringan untuk menyeimbangkan konsentrasi ROS. Antioksidan endogen seperti glutation, piruvat, dan lycopene diproduksi oleh tubuh untuk menghadapi akibat stres oksidatif. Jika konsentrasi antioksidan endogen tidak mencukupi atau tidak seimbang, perlu bantuan antioksidan eksogen. ${ }^{2}$ Antioksidan eksogen dapat diperoleh dari berbagai sumber seperti antioksidan sintetik (vitamin $\mathrm{E}$ dan Vitamin C) dan antioksidan alami yang bersumber dari tanaman. Jeruk purut(Citrus hystrix) adalah salah satu tanaman yang tumbuh di daerah Indonesia, Malaysia, dan Thailand. Sitronelal, suatu senyawa monoterpenoid yang memiliki aktivitas antioksidan, merupakan $80 \%$ penyusun dari minyak atsiri daun jeruk purut. ${ }^{3}$

Proses penuaan utamanya terjadi pada lapisan kulit bagian dermis. Maka antioksidan eksogen yang diberikan harus mencapai dermis sehingga dibutuhkan sistem penghantaran topikal karena sistem ini dapat meningkatkan permeabilitas kulit dan mempertahankan konsentrasi yang optimum dalam dermis. Studi in vivo menunjukkan formulasi liposom memiliki kemampuan penetrasi yang lebih baik akibat adanya sistem fosfolipid yang dapat menembus epidermis kulit dan penyerapan sistemik yang lebih rendah dibandingkan dengan formulasi konvensional. Formula liposom dapat digunakan untuk kulit sensitif dibandingkan etosom karena liposom tidak mengandung etanol yang dapat menyebabkan iritasi kulit. Liposom juga memiliki efek meningkatkan stabilitas zat baik terhadap lingkungan maupun oksidasi. ${ }^{4}$

Kelebihan yang dimilikiliposom memberikan peluang yang besar untuk membuat sediaan antipenuaan yang memiliki efektifitas antioksidan tinggi dan mampu berpenetrasi hingga ke lapisan dermis. Ekstrak yang diformulasikan dalam suatu sistem penghantaran liposom menimbulkan pertanyaan apakah ada perbedaan nilai aktivitas antioksidan antara ekstrak dan liposom ekstrak daun jeruk purut.

\section{Bahan dan Metode}

Bahan-bahan yang digunakan dalam penelitian ini ialah daun jeruk purut segar (Citrus hystrix) yang diperoleh dari UPT Materia Medika Batu, lesitin kedelai (Fischer Scientific), kolesterol (Sigma Aldrich), dapar fosfat pH 5, asam askorbat (Sigma Aldrich), reagen DPPH (Sigma Aldrich) dan pelarut etanol $96 \%$.

Pembuatan Ekstrak Daun Jeruk Purut:

Metode ekstraksi daun jeruk purut (Citrus hystrix) yang terpilih ialah dengan cara dingin yaitu maserasi. Daun jeruk purut kering dihaluskan dan diayak. Bubuk daun jeruk purut sebanyak $165 \mathrm{~g}$ dicampur dengan etanol $96 \%$ sebanyak $825 \mathrm{ml}$, diaduk dengan shaker, lalu didiamkan selama 48 jam. Hasil maserasi disaring dan diuapkan dalam rotary evaporator pada $60^{\circ} \mathrm{C}$ dengan kecepatan 80 rpm hingga mengental. Sisa pelarut diuapkan dalam oven lalu ditimbang.

Tes fitokimia terhadap ekstrak dilakukan dengan reagen tertentu. Ferric 
chloride test dengan reagen $\mathrm{FeCl}_{3}$ dilakukan untuk mengetahui kandungan fenol. Tes reagen alkali dengan penambahan $\mathrm{NaOH}$ dilakukan untuk mengetahui kandungan flavonoid. Uji Salkowski dilakukan dengan reagen kloroform dan $\mathrm{H}_{2} \mathrm{SO}_{4}$ untuk mengetahui kandungan terpenoid. ${ }^{5}$
Pembuatan Liposom:

Liposom yang dibuat dibedakan menjadi 3 formula atas dasar perbedaan konsentrasi lesitin. Lesitin merupakan komponen utama pembentuk vesikel liposom (Tabel 1).

Tabel 1. Formula liposom

\begin{tabular}{|c|c|c|c|c|}
\hline \multirow{2}{*}{ No } & \multirow{2}{*}{ Bahan } & \multicolumn{3}{|c|}{ Formula } \\
\hline & & $A$ & $B$ & C \\
\hline & Ekstrak daun jeruk purut & $0,5 \%(b / v)$ & $0,5 \%(b / v)$ & $0,5 \%(b / v)$ \\
\hline & Lesitin kedelai & $2 \%(b / v)$ & $3,5 \%(b / v)$ & $5 \%(b / v)$ \\
\hline & Kolesterol & $0,5 \%(b / v)$ & $0,5 \%(b / v)$ & $0,5 \%(b / v)$ \\
\hline & Kloroform:metanol $(3: 1, \mathrm{v} / \mathrm{v})$ & $20 \mathrm{ml}$ & $20 \mathrm{ml}$ & $20 \mathrm{ml}$ \\
\hline & Dapar fosfat pH 5 & $50 \mathrm{ml}$ & $50 \mathrm{ml}$ & $50 \mathrm{ml}$ \\
\hline
\end{tabular}

Liposom dibuat dengan menggunakan metode thin film hydration. Langkah pertama ialah membuat fase lipid terlebih dahulu dengan melarutkan ekstrak etanol daun jeruk purutdan lesitin kedelai dalam klorofommetanol (3:1 v/v) sebanyak $20 \mathrm{ml}$. Campuran pelarut diuapkan dengan rotary evaporator pada suhu $45^{\circ} \mathrm{C}$ untuk mendapatkan lapisan tipis lipid pada dinding labu. Lapisan lipid kering ditambahkan dapar fosfat $\mathrm{pH} 5$ pada suhu ruang. Dispersi yang dihasilkan dibiarkan pada suhu kamar selama 2-3 jam sehingga didapatkan suspensi vesikular MLV (multi lamellar vesicle). Selanjutnya, dilakukan sonikasi untuk mendapatkan liposom SLV (single lamellar vesicle)dari suspensi vesikular dalam bath ultrasonik 2 jam pada suhu kamar $\left(27^{\circ} \mathrm{C}\right)$.

Hasil pembuatan liposom diamati karakteristik organoleptik dengan cara melihat konsistensi, warna, dan bau secara langsung. ${ }^{6} \mathrm{Uji}$ nilai $\mathrm{pH}$ liposom menggunakan pH meter. PSA (particle size analyzer) digunakan untuk mengetahui ukuran dan transmission electron microscopy (TEM) untuk mengetahui morfologi vesikel. Selain itu, liposom juga dievaluasi terhadap daya penjerapannya karena dapat mempengaruhi efek antioksidan. Penentuan aktivitas antioksidan dilakukan dengan metode in vitro metode DPPH yang selanjutnya diamati dengan spektrofotometri UV-Vis.

Pemeriksaan nilai aktivitas antioksidan ekstrak dan liposom ekstrak yaitu uji pendahuluan, pemeriksaan nilai aktivitas antioksidan vitamin $\mathrm{C}$ sebagai pembanding, dan proses sentrifugasi liposom untuk mengeluarkan zat aktif dari vesikel. Metode pemeriksaan nilai aktivitas antioksidan dengan menggunakan metode DPPH yaitu 1 $\mathrm{ml}$ ekstrak tanaman dicampur dengan $3 \mathrm{ml}$ DPPH 100 ppm. Campuran diukur absorbansinya dengan standar asam askorbat pada $518 \mathrm{~nm}$ dengan menggunakan spektrofotometer UV-Vis. Nilai absorbansi yang didapatkan dimasukkan dalam rumus:

$$
\begin{aligned}
\% \text { Inhibisi }=[ & \left.\frac{\text { A kontrol }- \text { A sampel }}{A \text { kontrol }}\right] \\
& \times 100
\end{aligned}
$$

Uji stabilitas real timedilakukanuntuk mengetahui kestabilan sediaan selama 28 hari dalam suhu ruang $25^{\circ} \mathrm{C}$ dan kelembaban $\quad 60 \pm 5 \%$. Dipastikan bahwaselama 28 hari penyimpanan tidak ada 
perubahan organoleptik, ukuran, dan $\mathrm{pH}$. Analisis data dengan menggunakan aplikasi SPSS, pertama mengecek normalitas data, jika hasil normal maka dapat dilakukan metode repeated ANOVA, jika tidak normal maka menggunakan metode Friedman, untuk hasil data uji stabilitas. Hasil data uji nilai aktivitas antioksidan diperiksa normalitasnya, jika normal dapat dilakukan metode One way ANOVA, jika tidak normal maka menggunakan metode Kruskal Wallis.
Hasil

Dari proses ekstraksi didapatkan ekstrak kental yang didapatkan yaitu 16,2525 $\mathrm{g}$, rendemen yang didapatkan adalah $9,85 \%$. Hasil screening fitokimia yang dapat dilihat pada Tabel 2.

Tabel 2. Hasil screening fitokimia ekstrak daun jeruk purut

\begin{tabular}{llll}
\hline Pemeriksaan & Reagen & Perubahan Warna & Kesimpulan \\
\hline Fenol & $\mathrm{FeCl}_{3}$ & Kehitaman & $(+)$ Fenol \\
\hline Flavonoid & $\mathrm{NaOH}$ & Transparan & $(+)$ Flavonoid \\
\hline Terpenoid & Kloroform dan $\mathrm{H}_{2} \mathrm{SO}_{4}$ & Cokelat kemerahan & $(+)$ Terpenoid
\end{tabular}

Liposom yang telah dihasilkan kemudian dilakukan evaluasi karakteristik fisik. Uji organoleptik menunjukkan bahwa liposom berbentuk cair, berwarna hijau muda kekuningan, dan berbau segar khas daun jeruk purut. Terlihat pada Gambar 1. bahwa formula dengan kandungan lesitin yang lebih tinggi (F1C) memiliki warna yang lebih keruh.
Selain itu, liposom yang baru dibuat tersebut juga diukur nilai pH-nya. Hasil uji nilai $\mathrm{pH}$ liposom formula $\mathrm{A}$ yaitu 5,413 ; formula $B$ yaitu 5,686 ; dan formula $C$ yaitu 5,564. Dari hasil ini terlihat bahwa nilai $\mathrm{pH}$ liposom telah sesuai dengan spesifikasi $\mathrm{pH}$ kulit yaitu 4,5-6,5.

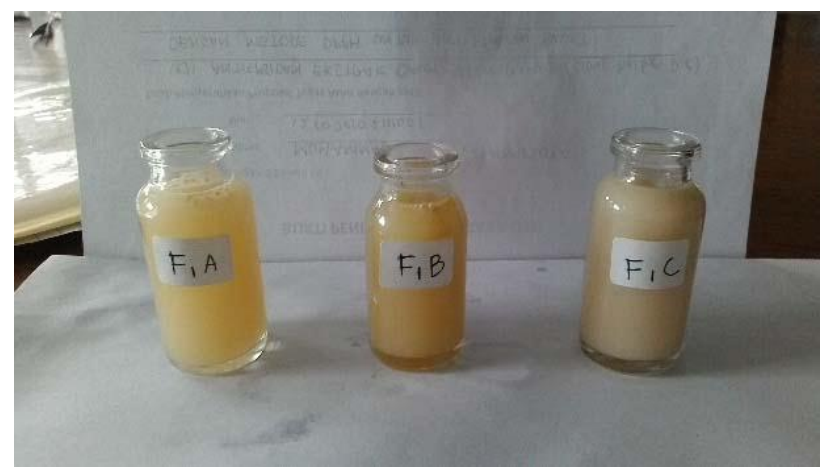

Gambar 1. Liposom ekstrak daun jeruk purut (formula A, formula B, formula C)

Uji Stabilitas:

Hasil uji stabilitas real time formula liposom menunjukkan tidak adanya perubahan bentuk, warna, dan bau namun ada endapan pada liposom hari ke-13 dan ke-28. Endapan tersebut akan hilang dengan pengocokan ringan.
Stabilitas juga diuji pada perubahan $\mathrm{pH}$ masing-masing formula. Pada formula $A$ disimpulkan bahwa ada perbedaan signifikan pada pengukuran hingga hari ke-28 (Friedman test, $p=0,000$ ). Sementara formula $\mathrm{B}$ dan $\mathrm{C}$ menunjukkan perbedaan signifikan pada pemeriksaan 3 titik (Friedman 
test, $p=0,005$ dan $p=0,000$ ). Nilai $p H$ pada

uji stabilitas dapat dilihat pada Tabel 3 .

Tabel 3. Hasil uji stabilitas pH liposom

\begin{tabular}{cccc}
\hline Formula & \multicolumn{3}{c}{$\mathrm{pH}$} \\
\cline { 2 - 4 } & Hari ke-1 & Hari ke-13 & Hari ke-28 \\
\hline A & 5,622 & 5,797 & 5,782 \\
\hline B & 5,632 & 5,683 & 5,755 \\
\hline C & 5,656 & 5,814 & 5,770 \\
\hline
\end{tabular}

Penentuan ukuran partikel liposom juga menjadi parameter penting dalam penelitian ini. Dengan menggunakan alat particle size analyzer, didapat diameter rerata partikel liposom. Pada analisis statistika, uji ukuran partikel pada uji stabilitas menunjukkan adanya perbedaan signifikan antara ukuran partikel hari ke-1, ke-13, dan ke-28 pada tiap formula liposom. Hasil uji ukuran partikel pada uji stabilitas terdapat pada Tabel 4.

Tabel 4. Hasil uji stabilitas ukuran partikel liposom

\begin{tabular}{cccc}
\hline Formula & \multicolumn{3}{c}{ Ukuran Partikel $(\mu \mathrm{m})$} \\
\cline { 2 - 4 } & Hari ke-1 & Hari ke-13 & Hari ke-28 \\
\hline A & 88,783 & 174,580 & 364,740 \\
\hline B & 53,203 & 73,243 & 106,403 \\
\hline C & 38,223 & 103,580 & 104,463 \\
\hline
\end{tabular}

Tidak hanya diameter rerata partikel liposom saja yang dapat terlihat oleh particle size analyzer. Distribusi ukuran partikel juga dapat terekam. Uji distribusi ukuran partikel menunjukkan distribusi yang tidak merata untuk seluruh formula liposom pada pemeriksaan hari ke-1, ke-13, maupun ke-28.
Uji Morfologi Liposom:

Hasil uji morfologi didapat dari pemeriksaan menggunakan TEM (transmission electrone microscope). Formula yang diajukan untuk pemeriksaan dengan TEM adalah formula C karena memiliki spesifikasi ukuran, organoleptik, nilai aktivitas antioksidan, dan $\mathrm{pH}$ yang paling baik. Terlihat pada Gambar 3 bahwa liposom memiliki bentuk hamper sferis. 
A
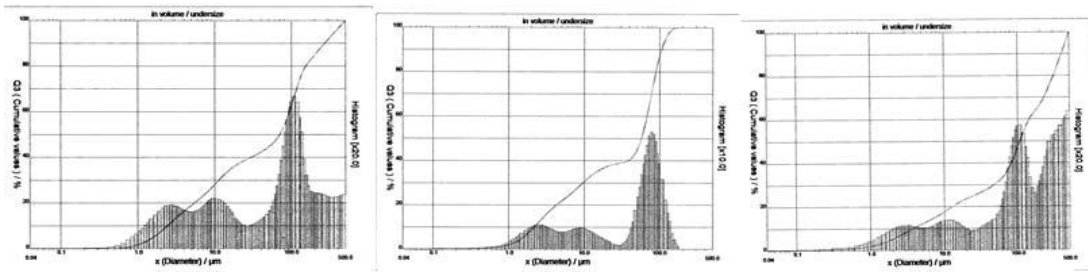

B
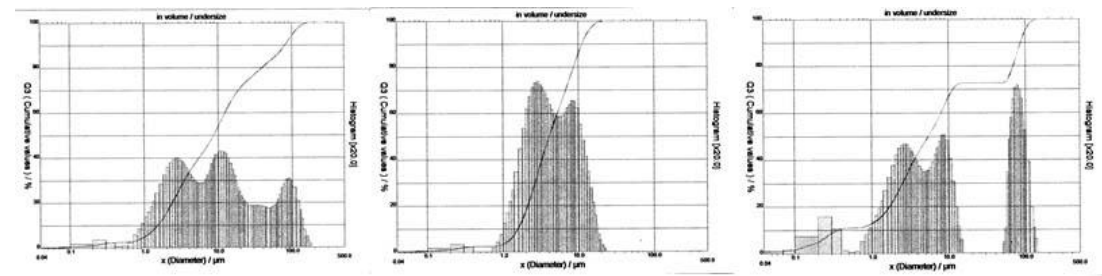

C
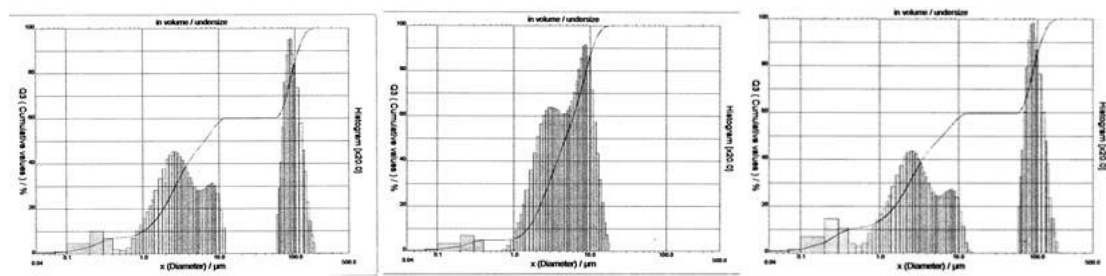

Gambar 2. Stabilitas distribusi partikel liposom ekstrak daun jeruk purut pada hari ke-1 (kolom kiri), hari ke-13 (kolom tengah) dan hari ke-28 (kolom kanan) Keterangan : Formula A (atas), Formula B (tengah), Formula C (bawah).

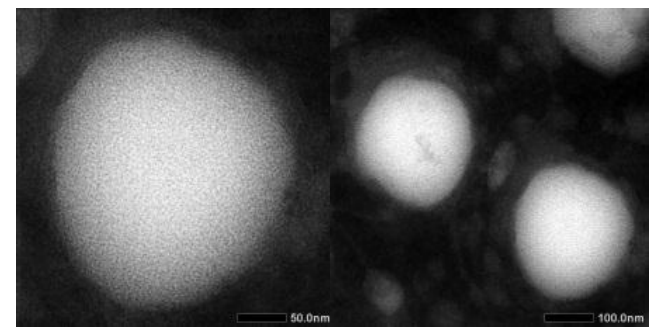

Gambar 3. Morfologi vesikel liposom

Uji Aktivitas Antioksidan:

Hasil uji pendahuluan antioksidan ekstrak dilakukan dengan menotolkan ekstrak dan vitamin Cpada KLT, lalu disemprot dengan DPPH 100 ppm. Uji ini ditujukan untuk screening efek antioksidan yang dimiliki, walaupun belum diketahui seberapa besar potensi antioksidan. Hasil uji pendahuluan dapat dilihat pada Gambar 4.

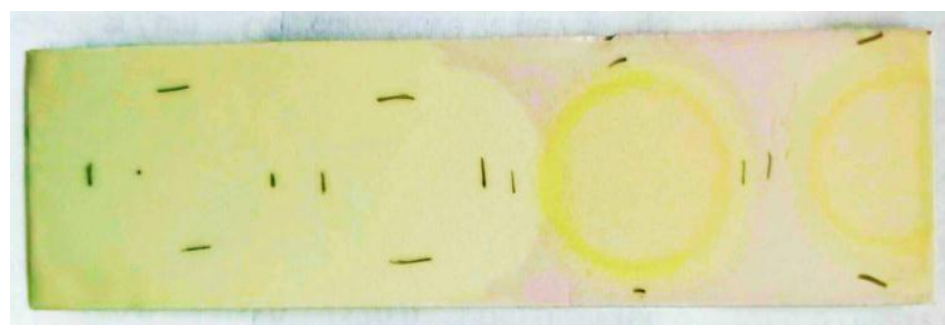

a b

C

d

Gambar 4. Hasil uji pendahuluan aktivitas antioksidan Vitamin C (a dan b) dan ekstrak daun jeruk purut (c dan d). Terlihat bahwa ekstrak daun jeruk purut memiliki efek antioksidan. 
Dari hasil uji nilai aktivitas antioksidan menggunakan metode DPPH, vitamin C memiliki nilai $I_{50}$ sebesar 4,793 ppm. Nilai aktivitas antioksidan ekstrak yaitu 27,434 ppm. Hasil uji nilai aktivitas antioksidan vitamin C, ekstrak, dan liposom terdapat pada Tabel 5. Dari tabel tersebut menunjukkan bahwa semakin kecil nilai $\mathrm{IC}_{50}$, maka semakin tinggi aktivitas antioksidan yang dimiliki. Berdasarkan uji statistik post hoc menunjukkan bahwa data yang berbeda signifikan adalah antara ekstrak dengan formula $B$ dan formula $C(p=0,023$ dan $p=$
0,001). Sedangkan antara ekstrak dan formula A tidak terdapat perbedaan secara signifikan $(p=0,162)$.

Nilai efisiensi penjerapan dari setiap formula liposom dapat dilihat pada Tabel 6.Nilai efisiensi penjerapan liposom didapatkan dari perhitungan presentase inhibisi supernatan yaitu membandingkan absorbansi ekstrak dan absorbansi supernatan liposom. Nilai efisiensi penjerapan didapat dari mengurangkan $100 \%$ dengan persentase inhibisi supernatan yang didapat sebelumnya.

Tabel 5. Hasil uji nilai aktivitas antioksidan $\left(\mathrm{IC}_{50}\right)$

\begin{tabular}{cc}
\hline Sampel/Formula & Nilai IC $_{50}(\mathrm{ppm})$ \\
\hline Liposom A & $28,187 \pm 0,24561$ \\
\hline Liposom B & $28,801 \pm 0,69001$ \\
\hline Liposom C & $29,876 \pm 0,08935$ \\
\hline Ekstrak & $27,434 \pm 0,67789$ \\
\hline Vitamin C & $4,793 \pm 0,047$ \\
\hline
\end{tabular}

Tabel 6. Nilai I $\mathrm{C}_{50}$, persentase inhibisi supernatan, dan efisiensi penjerapanliposom

\begin{tabular}{cccc}
\hline Formula & Nilai IC 50 & Persentase inhibisi supernatan & Efisiensi penjerapan \\
\hline A & 28,187 & $96,835 \%$ & $3,165 \%$ \\
\hline B & 28,801 & $94,848 \%$ & $5,152 \%$ \\
\hline C & 29,876 & $91,431 \%$ & $8,569 \%$ \\
\hline
\end{tabular}




\section{Pembahasan}

Hasil skrining fitokimia sesuai dengan determinasi bahan yang didapat dari UPT Materia Medika batu yaitu daun jeruk purut (Citrus hystrix) mengandung terpenoid dan minyak atsiri. Dalam minyak atsiri daun jeruk purut terdapat flavonoid dan fenol. Warna liposom hijau muda kekuningan sesuai dengan spesifikasi yang ditentukan sebelumnya karena adanya campuran lesitin kedelai dalam liposom. Bau dari liposom sesuai dengan spesifikasi yaitu segar dan khas daun jeruk purut (Citrus hystrix) sebagai zat aktif liposom. Hasil pengujian $\mathrm{pH}$ liposom berada dalam rentang yang diinginkan yaitu 4,5-6,5, sesuai dengan spesifikasi yang diinginkan. Rentang $\mathrm{pH} 4,5-$ 6,5 sesuai dengan $\mathrm{pH}$ kulit. ${ }^{7}$ Nilai $\mathrm{pH}$ kulit asam $(4-4,5)$ memudahkan flora normal menempel pada kulit, sedangkan $\mathrm{pH}$ basa (8-9) menyebabkan flora normal terlepas dari kulit. ${ }^{8}$

Ukuran partikel pada hari ke-1 diperiksa dengan alat PSA dengan hasil seluruh formula tidak memasuki spesifikasi yang diinginkan. Ukuran vesikel liposom yang $>1000 \mathrm{~nm}$ membuat liposom digolongkan sebagai GUV (giant unilamellar vesicles). GUV sudah banyak digunakan sebagai model liposom dalam studi penetrasi dalam membrane. ${ }^{9}$ Faktor yang dapat mempengaruhi ukuran partikel adalah waktu sonikasi dan amplitudo, semakin lama proses sonikasi maka ukuran partikel menurun dan semakin tinggi amplitudo sonikasi akan menurunkan pula ukuran partikel. Sonikasi pada frekuensi yang lebih rendah dapat mengurangi ukuran liposom lebih cepat. ${ }^{10}$ Metode pembuatan liposom mempengaruhi ukuran vesikel liposom yang terbentuk, dengan ukuran partikel terkecil didapat dari metode melting, lalu diikuti dengan metode sonication, reverse phase evaporation, thin layer evaporation, dan freezing thawing. ${ }^{11}$ Ukuran vesikel liposom dapat juga dipengaruhi oleh konsentrasi lesitin dalam formula. Konsentrasi lesitin yang tinggi dapat meningkatkan ukuran vesikel liposom. ${ }^{12}$

Hasil uji nilai aktivitas antioksidan yang telah dilakukan didapatkan hasil $\mathrm{IC}_{50}$ vitamin C 4,673 ppm, IC 50 $_{0}$ ekstrak 27,434 ppm, dan $\mathrm{IC}_{50}$ liposom untuk formula $\mathrm{A} 28,187 \mathrm{ppm}$, formula B 28,801 ppm, dan formula C adalah29,876 ppm. Nilai antioksidan ekstrak setelah diuji adalah lebih rendah daripada vitamin $\mathrm{C}$. Nilai $\mathrm{IC}_{50}$ ekstrak kurang dari 50 ppm hingga digolongkan ke dalam antioksidan sangat kuat. Hasil uji statistik menggunakan Oneway ANOVA, menunjukkan ada perbedaan signifikan antara nilai aktivitas antioksidan ekstrak dan liposom. Hasil ujipost hoc menunjukkan bahwa nilai $\mathrm{IC}_{50}$ ekstrak tidak berbeda dengan liposom formula $A$, namun berbeda dengan nilai $\mathrm{IC}_{50}$ formula $\mathrm{B}$ dan $\mathrm{C}$. Hal ini menunjukkan bentuk liposom dapat memperbaiki aktivitas antioksidan ekstrak, dan dipengaruhi oleh jumlah lesitin.

Nilai efisiensi penjerapan formula $A$ adalah paling kecil karena mengandung lesitin kedelai yang paling sedikit, selanjutnya formula B dan formula C menunjukkan nilai penjerapan yang lebih tinggi karena mengandung konsentrasi lesitin kedelai yang lebihtinggi. Nilai efisiensi penjerapan berbanding lurus dengan $\mathrm{IC}_{50}$, semakin tinggi $\mathrm{IC}_{50}$ liposom maka semakin tinggi efisiensi penjerapannya karena nilai $I_{50}$ menunjukkan potensi bahan aktif yang dapat menghambat zat oksidan akibat adanya efisiensi penjerapan yang dialami. ${ }^{1}$

Pada uji stabilitas terdapat perbedaan yaitu adanya endapan pada setiap formula liposom pada hari ke-13 dan ke-28. Pengendapan dalam liposom terjadi saat nilai tegangan permukaan vesikel dan buffer 
pelarut sama. Tegangan permukaan liposom dipengaruhi oleh fosfolipid, rasio molar kolesterol, dan konsentrasi obat. Tegangan permukaan liposom semakin menurun jika konsentrasi kolesterol dalam lapisan lipid meningkat. Peningkatan konsentrasi obat dapat meningkatkan tegangan permukaan liposom..$^{13}$

Hasil uji pH pada uji stabilitas liposomyang didapatkan telah sesuai dengan spesifikasi. Nilai pH yang berada di kisaran angka 5 didapatkan karena buffer fosfat yang digunakan sebagai pelarut dari liposom memiliki nilai $\mathrm{pH} 5$, namun nilai $\mathrm{pH}$ dari liposom juga dipengaruhi $\mathrm{pH}$ dari bahan yang digunakan hingga hasil akhir $\mathrm{pH}$ bervariasi.

Ukuran liposom yang diperiksa pada uji stabilitas meningkat seiring waktu karena liposom mengalami agregasi yang disebabkan oleh ikatan interaksi interpartikel. Barier dari potensial interaksi biasanya berasal dari kombinasi antara tolakan elektrostatik dan gaya Van der Waals. Gaya Van der Waals tergantung dengan ukuran partikel, semakin besar ukuran partikel, maka akan semakin mudah teragregasi. ${ }^{14}$ Pembentukan lapis tipis dalam rotary evaporator dalam formulasi yang dilakukan kurang merata dalam kondisi tebal atau tipisnya layer yang terbentuk, hingga dapat mengakibatkan ukuran vesikel yang bervariasi. ${ }^{15}$

Ekstrak daun jeruk purut memiliki aktivitas antioksidan terbukti dapat bereaksi dengan radikal bebas (DPPH) secara baik meskipun lebih rendah dari vitamin $\mathrm{C}$. Liposom sebagai sistem penghantaran obat tidak mempengaruhi aktivitas antioksidan dari ekstrak daun jeruk purut ditunjukkan dengan nilai $\mathrm{IC}_{50}$ dari liposom yang tidak lebihrendahnilai $\quad \mathrm{IC}_{50}$ ekstrak. Dengan digunakannya liposom sebagai sistem penghantaran obat tidak mempengaruhi aktivitas antioksidan ekstrak hingga liposom dapat dikembangkan kembali dengan memaksimalkan metode pembuatan liposom, alat, dan waktu penelitian.

\section{Kesimpulan}

Dari hasil penelitian dapat disimpulkan bahwa liposom formula $\mathrm{A}$ (jumlah lesitin $2 \%$ ) menunjukkan nilai aktivitas antioksidan yang tidak berbeda dengan ekstrak daun jeruk purut. Liposom formula B dan formula C (menggunakan lesitin masing-masing 3,5\% dan $5 \%$ ) menunjukkan aktivitas antioksidan yang lebih tinggi daripada ekstrak daun jeruk purut.

\section{Daftar Pustaka}

1. Stojiljković $D$, Dušica $P$, Ivana $A$. Oxidative Stress, Skin Aging and Antioxidant Therapy. Scientific Journal of the Faculty of Medicine in Niš. 2014; 31(4):207-217.

2. Pouillot A,Luigi LP,Philippe T,Alice N, Ada $P$,and Barbara P. Formulating, Packaging, and Marketing of Natural Cosmetic Products. New York : Wiley. 2011.

3. Mahalwal VS and AliM.Volatile Constituents of the Fruit Peels of $C$. reticulate. Blanco J Essent Oil Bearing Plants. 2001; 4:45-49.

4. Varun T. Niosomes and LiposomesVesicular Approach Towards Transdermal Drug Delivery. International Journal of Pharmaceutical and Chemical Sciences. 2012; 1(3).

5. Wagner $\mathrm{H}$ and Bladt S. Plant Drug Analysis: A Thin Layer Chromatography.2 ${ }^{\text {nd }}$ Ed. New York: Springer.1996.

6. Cardoso A.Total Phenolics Extracted from the Skin of Fuji Apple and 
Incorporated by Liposome in Galenic Bases: an Alternative to Use ByProducts of Food Industry. Romanian Biotechnological Letters. 2011; 16(6).

7. Saba MA and Gil Y. Skin pH: From Basic Science to Basic Skin Care. 2012; 93(3):261-267.

8. Lambers H, Piessens S, Bloem A, Pronk $H$, Finkel P. Natural Skin Surface $p H$ is on Average Below 5, which is Beneficial for its Resident Flora. Int $J$ Cosmet Sci. 2006; 28(5):359-70.

9. Wesołowska O, Krystyna M, Jadwiga M, and Hendrich AJ. Giant Unilamellar Vesicles - A Perfect Tool to Visualize Phase Separation and Lipid Rafts in Model Systems. 2009; 56(1):33-39.

10. Yamaguchi T, Nomura M, Matsuoka T, Koda S. Effects of Frequency and Power of Ultrasound on the Size Reduction of Liposome. Chemistry and Physics of Lipids. 2009; 160:58-62

11. Fan M, Xu S, Xia S, and Zhang X. Effect of Different Preparation Methods on Physicochemical Properties of Salidroside Liposomes.J Agric Food Chem. 2007; 55: 3089-3095 3089

12. Lasic DD and Barenholz $Y$ (Editors). From Gene Delivery and Diagnosis to Ecology. Di dalam: Handbook of Nonmedical Applications of Liposomes. Vol IV. Florida: CRC Press. 1996.

13. Butler El, Vargha M, Foldvari and Mezei M. Study of the Sedimentation Behaviour of Liposomal Drug Delivery System Colloids and Surfaces. Amsterdam: Elsevier Science Publishers. 1989. p 375-389.

14. Delgado AV. Interfacial Electrokinetics and Electrophoresis. $\mathrm{Di}$ dalam: Surfactant Science. Vol 106. Boca Raton: CRC Press. 2001.

15. Lee SC, Lee KE, Kim JJ, and Lim SH. The Effect of Cholesterol in the
Liposome Bilayer on the Stabilization of Incorporated Retinol Cholesterol in Liposomes Increases the Stability of Incorporated Retinol. J Liposome Res. 2005; 15:157-166. 